\title{
Production and Characterization of Coffee Husk Fuel Briquettes as an Alternative Energy Source
}

\author{
Assefa Tesfaye $\mathbb{D}^{1},{ }^{1}$ Fentahun Workie, ${ }^{2}$ and Venkatesh S. Kumar $\mathbb{D}^{1}$ \\ ${ }^{1}$ College of Engineering and Technology, Department of Mechanical Engineering, Mettu University, Mettu, \\ P.O. Box, 318, Ethiopia \\ ${ }^{2}$ Department of Mechanical Engineering, Mettu University, Mettu, P.O. Box, 318, Ethiopia \\ Correspondence should be addressed to Assefa Tesfaye; asefaseng2003@gmail.com
}

Received 28 June 2021; Revised 2 December 2021; Accepted 10 December 2021; Published 13 January 2022

Academic Editor: Antonio Caggiano

Copyright (c) 2022 Assefa Tesfaye et al. This is an open access article distributed under the Creative Commons Attribution License, which permits unrestricted use, distribution, and reproduction in any medium, provided the original work is properly cited.

\begin{abstract}
Biomass energy accounts for more than 92 percent of overall energy consumption in Ethiopia. As a result, Ethiopia is one of the world's most biomass-dependent countries. The high reliance on wood fuels and agricultural residues for fuel harms society's social, economic, and environmental well-being. This study aims to create and test the quality of fuel briquettes made from the coffee husk. Also built and produced are a carboniser/charcoal kiln, a manually operated molder system, and a briquette stove for burning the manufactured briquette. The carboniser converts $15 \mathrm{~kg}$ of raw coffee husk into $6 \mathrm{~kg}$ of carbonised char in 25 minutes, and the manually operated briquette molder can press $30 \mathrm{~kg}$ per hour. The efficiency of converting raw coffee husk into carbonised char content was $40.12 \%$. In the geological survey of Ethiopia, the geochemical laboratory directorate received triplicate samples of the fuel briquette charcoal for analysis. Moisture content, fixed carbon content, ash content, sulfur content, and calorific value were determined using a bomb calorimeter and a ceramic lining furnace. Physical properties of fuel briquettes ranged from $10.03 \%$ moisture content, $970 \mathrm{~kg} / \mathrm{m}^{3}$ density, $81 \%$ fixed carbon, $5.15 \%$ ash content, $0 \%$ sulfur, and $30.54 \mathrm{Kcal} / \mathrm{kg}$ higher heating value, according to laboratory results. The results of the study revealed that the coffee husk fuel briquettes produced have more positive characteristics. Fuel briquettes were cost-effective and environmentally friendly and reduced deforestation compared to firewood. This study clearly shows that briquettes made from coffee husk could be used as an alternative energy source when this kind of waste is well managed.
\end{abstract}

\section{Introduction}

1.1. Research Background. Fuel consumption is expected to rise in tandem with human population growth, causing a shift in the rate of industrial development in several countries. If demand exceeds supply by a large margin, a fuel crisis is likely to occur, necessitating renewable alternative energy [1]. In Ethiopia, the most common cooking fuels are wood and charcoal, which most rural populations use [2-4]. The collection of wood is challenging for women and girls. Cooking on three-stone fires is common, resulting in indoor air pollution and adverse health effects. Furthermore, high $\mathrm{CO}_{2}$ emissions, deforestation, and land degradation are all consequences. Coffee husk is one of the most common agricultural wastes available in the Ethiopian mountain regions, which, through various thermochemical conversion processes, has been turned into different types of fuel and chemical feedstocks. Coffee is one of the world's most consumed drinks. More than 3.5 billion cups of coffee are used and consumed on the planet every day, according to FAO studies [5]. In more than 70 countries, coffee plants are cultivated [6-8]. Experiments show that coffee briquettes with a combustion property similar to firewood can be used as a renewable fuel. Since the amount of burned debris in the open areas is reduced by briquette combustion and thereby emissions, the ecosystem would benefit considerably. In Ethiopia, approximately 3,300,000 tonnes of surplus coffee, cotton, wheat, and barley residues are produced yearly, but not all of them are economically accessible; even the Ethiopian energy economy has been substantially reduced by the 
much-distributed figure of the residues from centralised state farms, estimated at 600,000 tonnes [9-11]. The briquetting method for the conversion of agricultural waste into uniformly formed briquettes is easily usable, transportable, and storable. Coffee husks are currently a good material for briquetting $[12,13]$. In mid-1985, Addis Ababa opened one of the few known private briquetting plants in Africa in Ethiopia [14]. Once the information was received about similar plants in India, private individuals purchased a low-pressure piston machine supplied by Eco-Briquette. The raw material is sawdust $(60 \%)$ plus coffee and cottonseed husk. The briquettes are mainly sold in middle-class hotels of Addis with sophisticated fireplaces. The system functions reliably, but the drawback is the need for a binder that must be imported from abroad. A devotion allowance for this is difficult to get, and the binder costs require most of the plant's operating costs. In 1988, however, owners anticipated that their production would increase to about 3,000 tonnes if sufficient raw material was to be obtained. A major briquetting program focused on several agribusinesses from state-owned farms is planned for Ethiopia. These activities have not yet begun $[9,15-17]$.

The torrefaction rate is affected by particle size, especially at high temperatures. Although the temperature gradient inside particles smaller than $1 \mathrm{~mm}$ is very small during torrefaction, the internal diffusion of generated vapors inside the particles imposes an impact on the global torrefaction reaction rate. The hardcore or nonshrinkage particle model with a first-order torrefaction reaction can predict the reaction data reasonably well, with the data-fitted effective vapor diffusivity coefficient. The densification tests showed that more energy was required to make pellets from larger torrefied particles, while the water uptake and Meyer hardness tests of pellets revealed that the good quality torrefied pellets could be obtained from fine torrefied sawdust particles [18]. The increase of temperature in the torrefaction process reduces the residence time needed to achieve the maximum higher heating value. As a result, the optimum conditions of torrefaction for olive biomass were, approximately, $275^{\circ} \mathrm{C}$ and $30 \mathrm{~min}$ of residence time. This reaction yielded an optimum 5,830 cal/g higher heating value [19].

Torrefaction was used to turn low-quality feedstocks into high-quality briquettes, and their attributes were compared to coal briquettes. The reactivity, content, and structure of the resultant materials were investigated. Thermogravimetric investigation revealed that the $\mathrm{CO}_{2}$ reactivities of composite material and coal are mostly influenced by the heat treatment temperature, the organic composition of the feedstock, and the porosity of the material, with ash composition of the original feedstock playing a minor role. The differences in calorific value were attributed in part to moisture content and organic composition of the feedstock, as determined by $13 \mathrm{C} \mathrm{CP/MAS} \mathrm{and} \mathrm{proximate} \mathrm{analysis.}$ Using the XCT technology, a new approach was devised to assess the feedstock porosity, which discovered three solid phases in a briquette. Quartz retention in particles from natural feedstock was found in the inorganic portion of both biomass and coal briquettes. Torrefaction of low-quality biomass yielded terrified biomass briquettes with reactivity comparable to coal briquettes. The outcomes of this study highlight the possibility for low-quality biomass to be used in the energy industry, resulting in a reduction in $\mathrm{CO}_{2}$ emissions [20].

Due to the high solid char yield, low reactivity, and more favorable thermal conductivity values, Anna Trubetskaya et al. found that olive stones of less than $2 \mathrm{~mm}$ from torrefaction at $270^{\circ} \mathrm{C}$ for $30 \mathrm{~mm}$ are the best acceptable material for briquetting with coal on a pilot scale. The inorganic matter and lignocellulose composition of the original olive stones both had an equal effect on the intrinsic reactivity of the material, according to thermogravimetric measurements. The size reduction of olive stones resulted in a higher ash content in small particles and consequently a higher calcium concentration of 40 than that in large olive stones. In comparison to the material made up of larger grains, F-SIMS results revealed that the olive stones with a size of less than $0.425 \mathrm{~mm}$ contained more cellulose than lignin on the particle surface. The olive stone torrefaction holds a lot of promise for manufacturing sustainable biomass briquettes with calorific values comparable to that of peat and thermal conductivity values below solid fuel explosive limitations. The outcomes of this study highlight the potential for frightened olive stones to be used in the energy industry, resulting in lower $\mathrm{CO}_{2}$ emissions $[18,21]$.

Briquettes created from coffee husk have a lot of potential as an environmentally beneficial energy source, according to the present study. It decreases pollutants while also ensuring that coffee waste is properly disposed of. Furthermore, the production of briquettes from coffee husk helps to increase the process of carbon sequestration by preventing deforestation by providing renewable, clean, and sustainable energy as an alternative for fuelwood and charcoal. This research work involves converting coffee husk to char in an environmentally benign, continuous batch process, briquetting the char into a solid fuel shape and employing briquettes as fuel in a dependable, clean, and user-friendly stove.

The briquette production technologies employed in each phase are straightforward to use in rural regions, allowing the Mettu region to tap into new revenue streams. This method promises to transform coffee husk waste into a lowcost, ecologically friendly briquette fuel for homes, restaurants, and small enterprises.

\section{Materials and Methods}

2.1. Materials. Sheet metal, square pipe, round pipe, screw, coffee husk, flat plate metal, round bar, angle iron, and clay soil are the primary materials used in this study. The materials chosen are based on cost and availability in the region.

The charcoal kiln was constructed out of sheet metal. The square pipe was utilized to construct the machine's legs and frame. The circular pipe was crucial in the construction of the molding machine's chimney, handle, and body. A screw was used to raise and lower the molding machine. For the manufacturing of fuel briquettes, clay soil is employed as a binding ingredient. The kiln was supported by a frame built 
of angle iron. Making holes for the fuel briquettes was done using the round bar. The flat plate metal was utilized as a kiln handling mechanism as well as for removing the kiln cover.

2.2. Study Site Description and Sampling Technique. In Oromia Regional State, Illu Aba Bora Zone, Mettu city, the Dagim, and Dechaok coffee-processing industries were chosen for this study. They are situated at $8.300^{\circ} \mathrm{N}$ latitude, $35.583^{\circ} \mathrm{E}$ longitude, and $1,605 \mathrm{~m}$ above sea level. The two coffee-processing industries were chosen purposively as a source of enormous coffee husk. This massive amount of coffee husk allowed us to obtain sufficient quantities and a uniform type of coffee husk. Mettu University provided us facilities and services for the manufacturing of charcoal kiln, chimney, and manually operated molder. The experimental results of the fuel briquettes were obtained at the Geological Survey of Ethiopia, Geochemical Laboratory in Addis Ababa.

2.3. Briquetting Process. Briquetting is one of the lightweight technologies that can generate a product that has higher bulk density, less moisture content, and consistent form, shape, and material characteristics [22]. A manually operated briquette molder is used to shape the charcoal mixture into briquettes (Figures 1(a) and 1(b)). The series steps involved in the briquetting process are mentioned in Figure 2.

2.3.1. Biomass Collection. A large amount of coffee husk has been found in Mettu city, and the husk is being discarded. As a result, the coffee husk was chosen as a biomass waste with a moisture content of $10.03 \%$ (Table 1) for this plant. We gathered waste from coffee husk producers and dried it out in the sun to make it suitable for burning (Figure 3).

2.3.2. Coffee Husk Carbonisation and Charcoal Kiln Construction. The charring kiln (Figure 4) for large sizes is a portable cylindrical device with a chimney cut out at the center. As can be seen from Figure 5 and Figure 6, the drum has a height of $100 \mathrm{~cm}$ and a width of $66 \mathrm{~cm}$ and made of $2.5 \mathrm{~mm}$ thick sheet metals. Two fire ports with doors $(5 \mathrm{~cm}$ height $x 10 \mathrm{~cm}$ width) were given on the lower side. Above the firing section, a perforated iron sheet with holes is fixed. The drum's bottom side was covered by iron sheets and supported by four legs (Figures 5-7).

2.4. Coffee Husk to Carbonised Material Conversion. Before carbonisation, the coffee husk was allowed to dry to extract moisture and aid in the carbonisation process. A $20 \mathrm{~kg}$ sample of coffee husk was carbonised separately in an oxygen-depleted atmosphere for each treatment. This process was carried out three more times. The efficiency of converting raw coffee husk into carbonised material was determined as follows [23, 24]:

$$
\mathrm{CE}=\frac{m_{-} c}{m_{-} s} * 100[\%],
$$

where $\mathrm{CE}$ is the carbonisation efficiency, in \%; $\mathrm{mc}$ is the the mass of carbonisation sample, in $g$; and $\mathrm{ms}$ is the mass of the sample before carbonisation, in $g$.

2.5. Charcoal Kiln/Carboniser Design Considerations. When a low-oxygen atmosphere is heated to a high temperature, carbon is produced. The carboniser is a device that is engineered, manufactured, and used to create a low-oxygen atmosphere. The carboniser is constructed from a cylindrical oil drum and two conical metal shapes welded to the ground (Figure 4). The upper section has 24 holes in the ground for smoke removal, while the lower section has no troughs, so the smoke path is pushed upward by a cylindrical tube inserted at the center of the carboniser and welded by the two conical shapes. After applying the dried coffee husk, it is then sealed on top (Figures 4 and 6).

2.5.1. Using Coffee Husk to Make Fuel Briquettes. As shown in Figure 3, the coffee husk was collected from the nearby coffee-processing plants such as Dagim and Dechaok. After that, the coffee husk was sun-dried. The dried coffee husk was then burned in the carboniser for 45 minutes to 1 hour (depending upon the nature of the coffee husk). We were able to obtain $30 \%$ carbonised char using this process (Figure $8(\mathrm{a})$ ). The carbonised char was ground into fine particles and combined with a binder in a $4: 1$ ratio (Figure 8(b)), meaning that for every four kilograms of ground carbonised char, one kilogram of binder was added. As a binding material, we used clay soil. A manually operated briquette molder (Figures 1(a) and 1(b)) was then used to transform the mixture into briquettes. This was accomplished by pouring the mixture into a manually operated briquette molder and ramming it with the aid of an auger using a handle. The blended char powder is then packed tightly into the manually operated cylindrical molder. Finally, the cylindrical briquettes were laid out on a suitable surface to dry in the heat.

2.6. The Binder Preparation. The binder material is used to make the briquettes stronger. Different binders, such as commercial starch, rice powder, cassava, waste paper, and other cost-effective materials like clay soil, can be mixed with carbonised char powder in various amounts and molded with the aid of a manually operated briquetting molder.

2.7. Mixing. Briquetting includes the addition of a binder to the charcoal fines and the use of a press to shape the mixture into a cake or briquette. Many binders have been tried, but the most common successful binder is clay, as previously mentioned. In this research work, clay is employed as a binder. However, the clay content in the briquettes should be less than $15 \%$. If there is too much clay in the finished charcoal briquette, it can burn poorly or even be inflammable. Mix until the binder is uniformly dispersed in the carbonised charcoal. It will increase the adhesion of the charcoal and produce briquettes that are identical. The clay hardens as the water evaporates, forming a briquette that can 


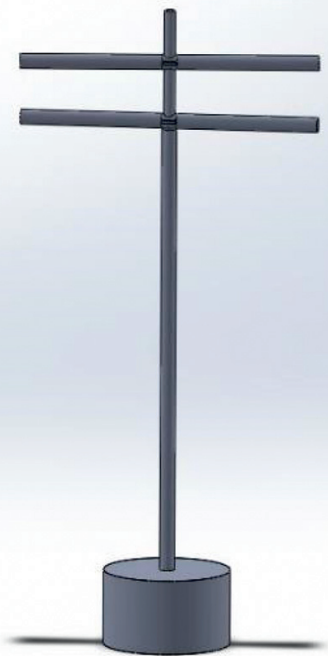

(a)

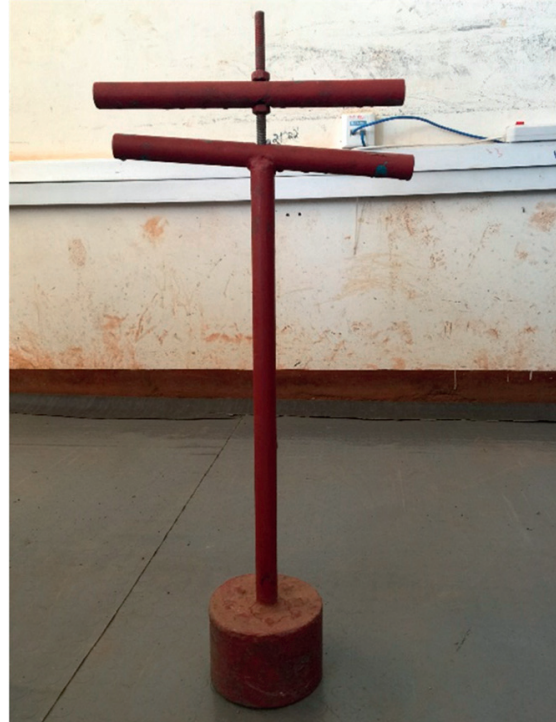

(b)

FIgURE 1: (a, b) Manually operated briquette molder.

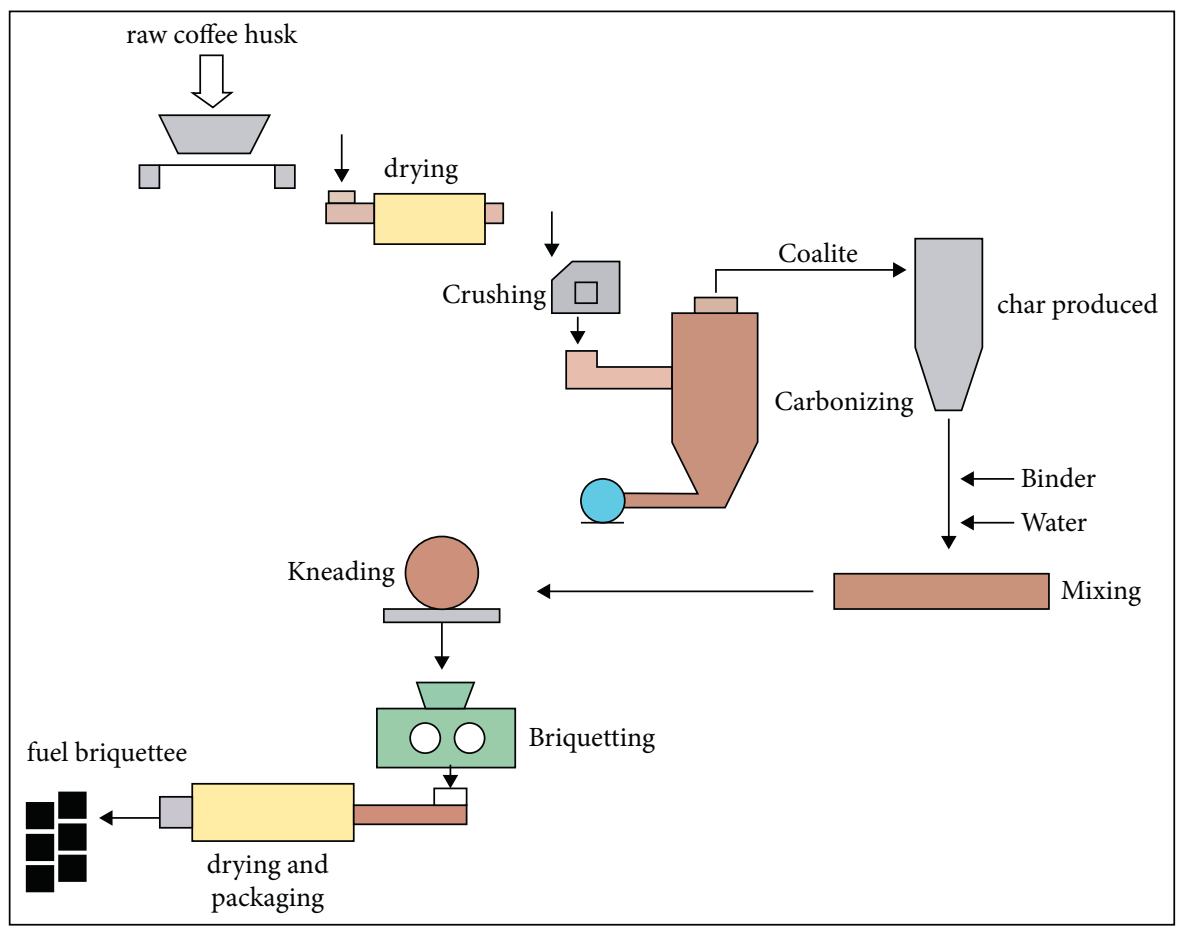

Figure 2: Process flow of briquette production.

TABle 1: Proximate analysis of fuel briquettes [7, 24, 26, 29, 41, 43].

\begin{tabular}{lccc}
\hline S. no. & Pyrolysis analysis & Value & Standard values \\
\hline 1 & Moisture content (\%) & 10.03 & $10-14$ \\
2 & Volatile matter (\%) & 12.6 & $20-25$ \\
3 & Fixed carbon (\%) & 81 & $50-95$ \\
4 & Ash content(\%) & 5.15 & $3-4$ \\
5 & Sulfur $(\%)$ & 0.00 & 0.0 \\
6 & HHV (MJ/kg)/ISO 1928 & 30.54 & Above 29.30 \\
7 & Density $\left(\mathrm{Kg} / \mathrm{m}^{3}\right)$ & 970 & Up to 1000 \\
\hline
\end{tabular}



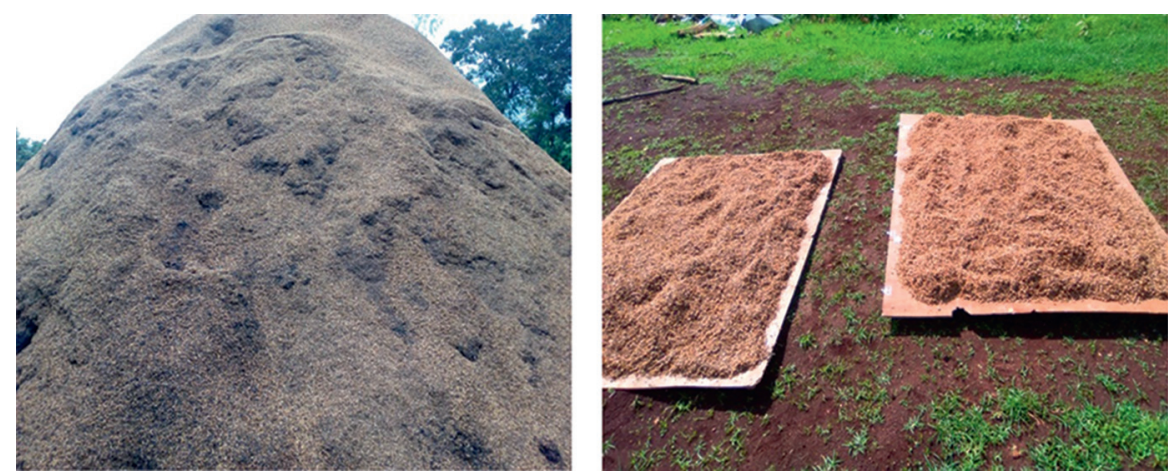

Figure 3: Coffee husk collected from industries.
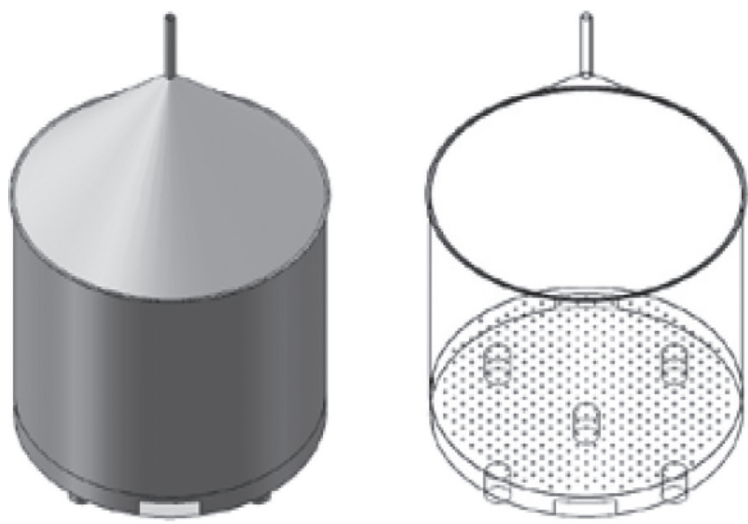

FIgURE 4: Production of carboniser/charcoal kiln.
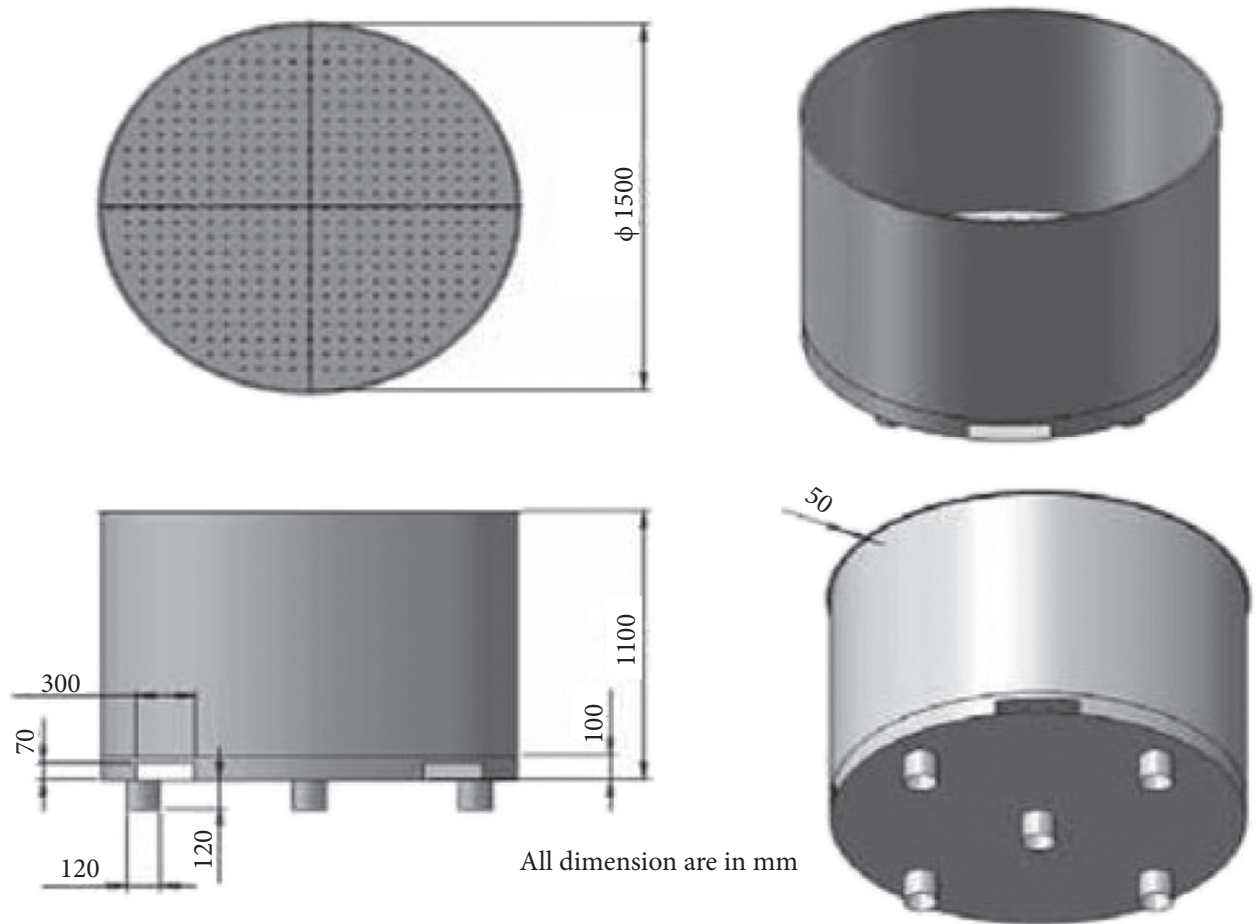

FIGURE 5: Charcoal kiln. 

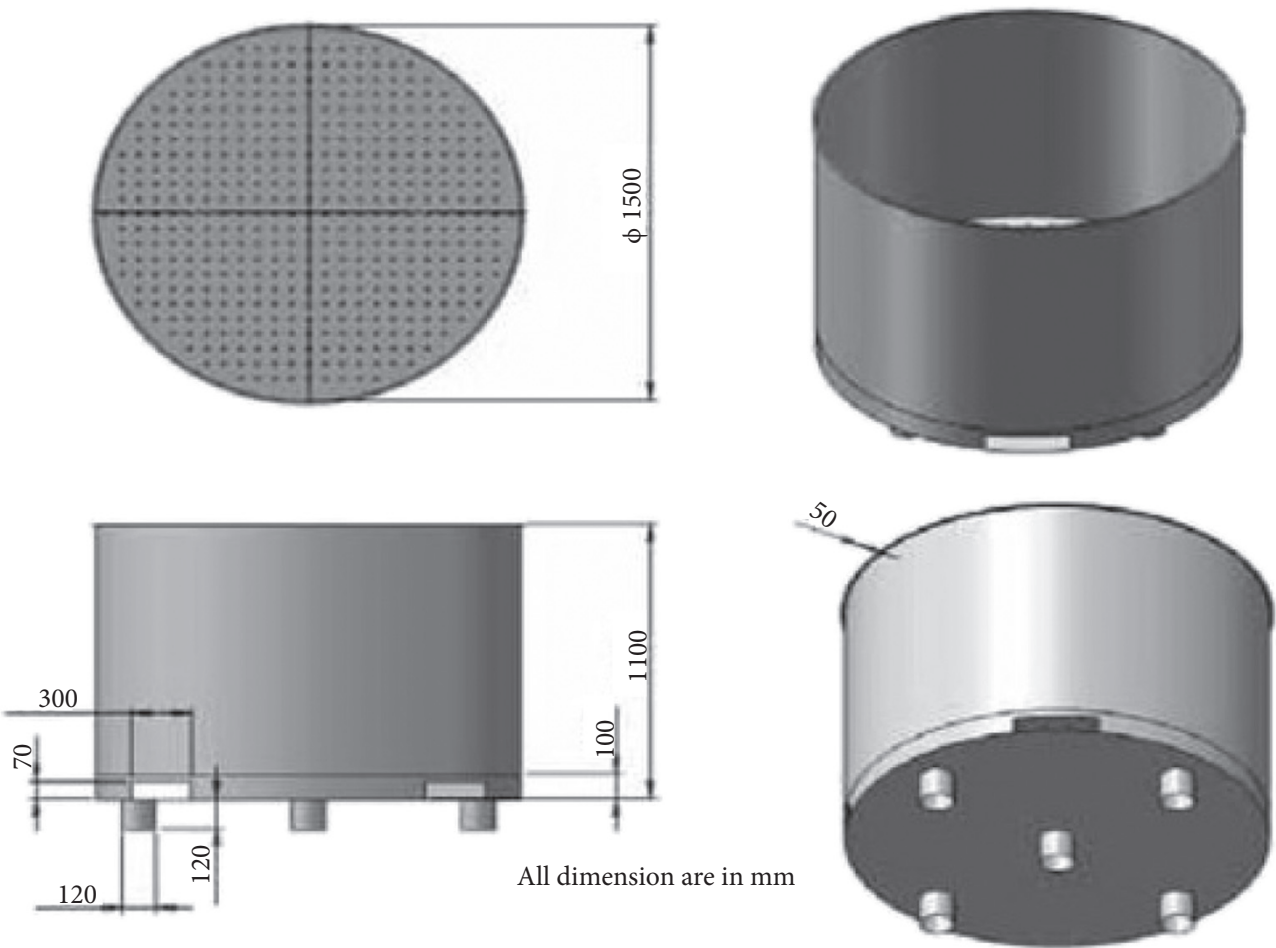

Figure 6: Charcoal chimney.

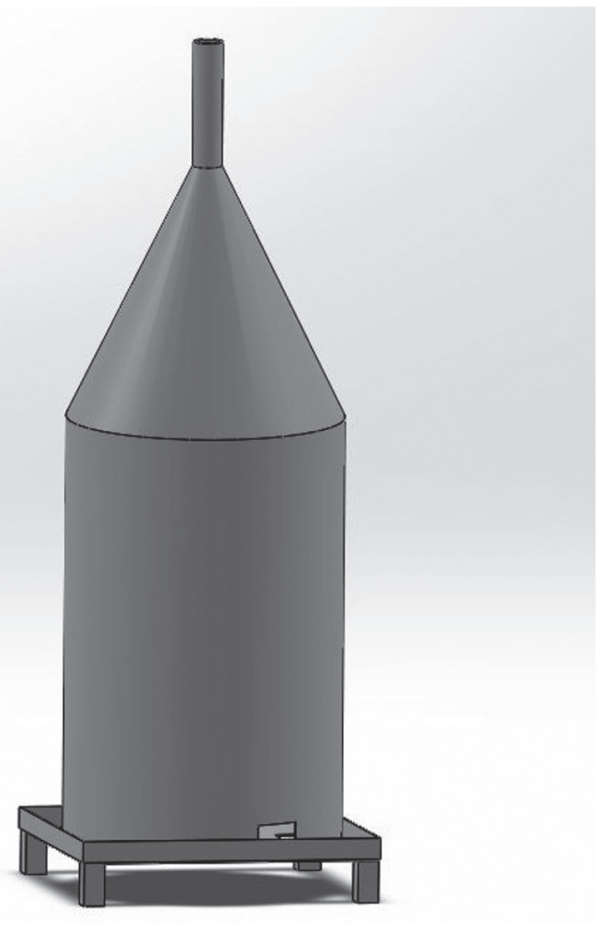

Figure 7: Charcoal kiln. 


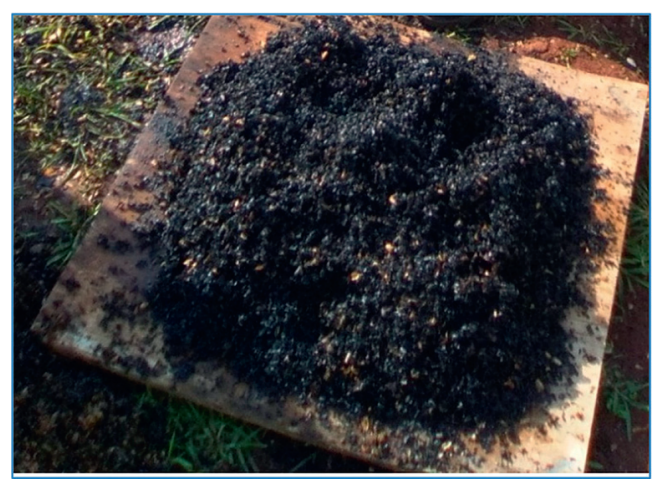

(a)

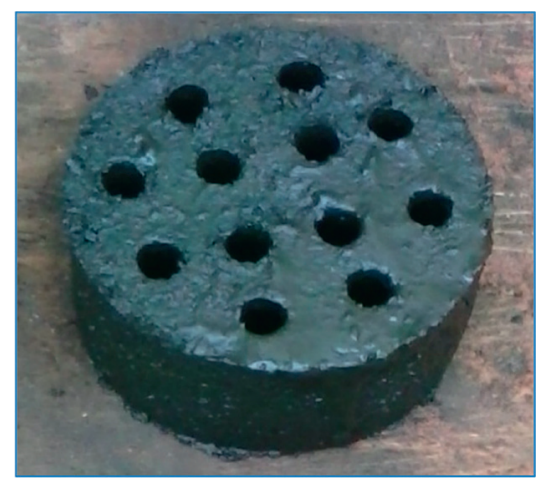

(b)

Figure 8: Preparation of fuel briquette using coffee husk char. (a) Fuel briquette. (b) Carbonised char.

be treated and burned in domestic stoves and grates like regular lump charcoal.

\subsection{Manually Operated Briquette Molder (MOBM). The fuel} briquette molder was designed and constructed to produce one briquette charcoal at a limited $20 \mathrm{~cm}$ diameter. As can be seen from Figure 1, the briquettes were made in a cylindrical mold with an inner diameter of $114 \mathrm{~mm}$, a height of $74 \mathrm{~mm}$, and a $14 \mathrm{~mm}$ outer diameter rod inserted in the center to make a hole in the middle. The hole improves briquette combustion by increasing porosity and oxygen supply. The punch holder and housing are made of sheet metal. The punch guide is made of steel. The punch, stand, and mold adjuster are all made of a round bar. For the standpipe and the handle, a pipe is used (Figure 1(a) and 1(b)).

The molder is made of thick sheet metal welded to a solid round steel rod and is built to manufacture high-density briquettes with holes to enable the charcoal to burn more easily. The mixed char can be rammed after it has been fed into the molder. The materials can be pressed against the holes at the end of the molder to create light and standardised size briquettes since the end of the molder is a kind of circular shape with some holes (Figures 1(a) and 1(b)).

2.9. Drying and Packing Process. The briquettes were collected in a suitable tray and dried for around 1-4 days in the sun before being packaged in plastic bags for end users. Sunlight is used to extract moisture from the briquette; otherwise, it will be difficult to burn and decrease the fire's effectiveness.

2.10. Laboratory Analysis. Moisture content, volatile matter, ash content, fixed carbon content, calorific value, bulk density, and sulfur content were determined in triplicate samples of dried briquettes from each treatment at the Geological Survey of Ethiopia, Geochemical Laboratory in Addis Ababa.

\subsubsection{Proximate Analysis}

(1) Moisture Content. The moisture content (MC) of the fuel briquette was calculated using the American Society for Testing Materials' standard process [24-26]. This is achieved based on dry biomass, which was calculated by weighing samples of the collected briquette $\left(\mathrm{W}_{1}\right)$ and oven-drying them at $105^{\circ} \mathrm{C}$ for 60 minutes until the constant weight $\left(\mathrm{W}_{2}\right)$ was obtained. Using the following equation, the difference in weight $\left(\mathrm{W}_{1}-\mathrm{W}_{2}\right)$ was determined to determine the sample's percentage moisture content:

$$
\mathrm{MC}=\frac{\left(W_{1}-W_{2}\right)}{W_{2}} * 100[\%],
$$

where $W_{1}=$ initial weight of the sample before drying, in $g$, $W_{2}=$ final weight of the sample after drying, in $g$, and $\mathrm{MC}=$ percentage of moisture content, in \%.

(2) Volatile Matter (VM). The briquette's volatile matter (VM) content was determined using the standard method CEN/TS 15148 [24, 26-32]. It was determined by heating an oven-dried sample in absence of oxygen at $950^{\circ} \mathrm{C}$ for six minutes. The volatile matter was computed as the difference between the initial weight and final weight of the sample to the ratio of the weight of the briquette sample. The volatile matter was calculated using the following equation [24, 33-35]:

$$
\mathrm{VM}=\frac{\left(W_{1}-W_{2}\right)}{W} * 100[\%]
$$


where $W_{1}=$ initial weight of the sample at $105^{\circ} \mathrm{C}$, in $\mathrm{g}$, $W_{2}=$ final weight of the sample at $950^{\circ} \mathrm{C}$, in g, $W=$ weight of briquette sample, in $\mathrm{g}$, and $\mathrm{VM}=$ percentage of volatile matter, in \%.

(3) Ash Content. The briquette sample was heated in a crucible at $750^{\circ} \mathrm{C}$ for three hours in the oven to determine the ash content. The ash content was determined by dividing the weight of the briquette ash by the weight of the briquette sample as follows [24, 33-38]:

$$
\mathrm{AC}=\frac{\left(W_{1}-W_{2}\right)}{W} * 100[\%],
$$

where $W_{1}=$ weight of sample at $950^{\circ}$, in $\mathrm{g}, W_{2}=$ weight of sample at $750^{\circ}$, in $g, W=$ weight of briquette sample, in $g$, and $\mathrm{AC}=$ percentage of ash content, in \%.

(4) Fixed Carbon. The percentage of the fixed carbon content of the briquettes was calculated by subtracting the amount of volatile matter, ash content, and moisture content from 100, and the percentage of the fixed carbon content of the briquettes was calculated [24, 33-35].

$$
\mathrm{FC}=100 \%-(\mathrm{MC}+\mathrm{VM}+\mathrm{AC}),
$$

where $\mathrm{VM}=$ volatile matter, in $\%, \mathrm{AC}=$ ash content, in \%, $\mathrm{MC}=$ moisture content, in \%, and $\mathrm{FC}=$ fixed carbon, in \%

\subsubsection{Determination of Bulk Density, Sulfur Content, and Calorific Values}

(1) Bulk Density (BD). The bulk density of the briquette was expressed as the ratio of the mass of the briquette to the volume of the briquette $[24,33,35,39-42]$.

$$
\mathrm{BD}=\frac{m_{-} s}{V_{-} s}[\%],
$$

where $\mathrm{BD}=$ bulk density of the briquette, in $\%, m_{-} s=$ mass of briquette sample, in $\mathrm{g}$, and $V_{-} s=$ volume of briquette sample, in cc.

(2) Sulfur Content (SC). The sulfur content was measured using a Parr (1241) adiabatic oxygen bomb calorimeter through calorimetric combustion of the briquette sample according to $[24,33,34]$ as follows:

$$
\mathrm{SC}=\frac{\left(w_{-} d-b_{-} e\right) * 13.73}{w_{-} s}[\%],
$$

where SC = sulfur content, in \%, w_d = weight difference, in $\mathrm{g}, \mathrm{b} \_e=$ blank weight, in $\mathrm{g}$, and $\mathrm{w}_{-} s=$ weight of briquette sample, in $\mathrm{g}$.

(3) Calorific Value (CV). The calorific value of the briquette was measured using a Parr (1241) adiabatic oxygen bomb calorimeter as follows [24, 33-35]:
$\mathrm{CV}=\frac{\Delta T^{f} \times 2420-\left(\text { wire burn } \times 2.3+\text { Titration }+ \text { sulfur }^{\mathrm{g}}\right)}{w_{-} s}$,

where $\mathrm{CV}=$ calorific value, in cal, $\Delta T^{f}=$ final change in temperature, ${ }^{\circ} \mathrm{C}$, and $\mathrm{w}_{-} s=$ weight of briquette sample, in $g$.

\section{Results and Discussion}

3.1. Laboratory Results. The carboniser or kiln shown in Figure 4 was developed to produce $5 \mathrm{~kg}$ of briquette charcoal, made of $15 \mathrm{~kg}$ of input biomass and burns for approximately 25 minutes, using only coffee husk in this experiment. The manual molding machine has a pressing power of $30 \mathrm{~kg} / \mathrm{h}$. The average moisture content of the coffee husk was $10.03 \%$ (Table 2). In addition, the volatile matter of the coffee husk was $12.6 \%$ (Table 1). As shown in Table 1, the carbon dip level of the briquette will vary from $80 \%$ to $82 \%$ or higher, depending upon the quantity and dryness of the input material on the carbon kiln. As briquettes lose their fume during carbonisation in a charcoal kiln, they do not cause smoke and smoothly burn out due to their low sulfur content. As shown in Table 1, the calorific value (HHV), in $\mathrm{MJ} / \mathrm{kg}$, of the fuel briquette is $30.543 \mathrm{MJ} / \mathrm{Kg}$ and it has a density of $970 \mathrm{~kg} / \mathrm{m}^{3}$. All the proximate analyses of the coffee husk have been presented in Table 1. It is combustible for around $2-3$ hours as the benefit of heating and briquetting is substantially higher. Using $100 \mathrm{~g}$ fuel briquettes, the stove can cook meals for more extended periods (Figure 9).

\subsection{Discussion}

3.2.1. Effect of Temperature on Yield and Quality of Produced Char. Other parameters such as heating time, heating rate, and material type should be kept constant to demonstrate the influence of temperature. Table 3 presents the effect of temperature on yield and produced char.

As illustrated in Figure 10, the yield of char decreases as the temperature of the carboniser rises but the quality of the char improves. The decrease in the biochar yield as temperature rises could be attributed to increased breakdown (decomposition of biomass to volatile matter, ash content, tar, and fixed carbon) or secondary decomposition (crack of volatile fractions into low molecular weight liquids and gases) of char residues. The significant production of biochar at moderate temperatures suggests that just a portion of the material has been pyrolyzed. The char quality is largely dependent on fixed carbon content, and as temperature rises, so does the amount of fixed carbon content, resulting in an increase in char quality, as indicated in Figure 10. However, the quantity (yield) of char should be considered, and the carboniser's temperature should be kept at $500^{\circ} \mathrm{C}$ because the char has good quality but a slightly lower yield at this temperature (Figure 10). 
TABle 2: Moisture content of coffee husk [9].

\begin{tabular}{lcccc}
\hline S/N & Sample type & Initial mass before drying (in gr.) & The final mass of the sample after drying (in gr.) & Moisture content (\%) \\
\hline 1 & Coffee husk 1 & 20 & 18.12 & 9.40 \\
2 & Coffee husk 2 & 20 & 18.01 & 9.95 \\
3 & Coffee husk 3 & 20 & 17.85 & 10.75 \\
& & Average moisture content of coffee husk & & 10.03 \\
\hline
\end{tabular}

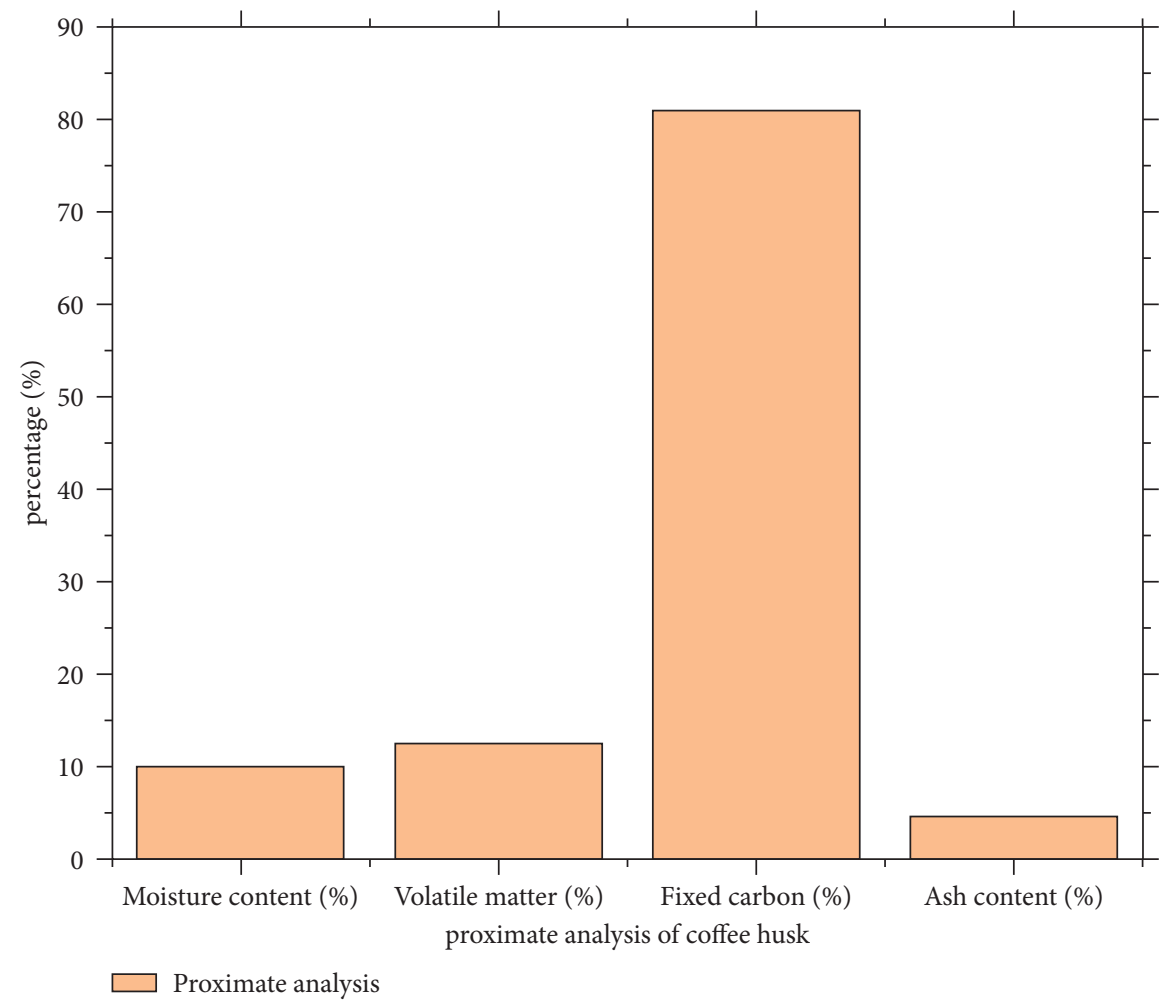

Figure 9: Proximate analysis of coffee husk.

TABLE 3: Effect of temperature on yield and quality of char.

\begin{tabular}{lccccccc}
\hline $\begin{array}{l}\text { Temp } \\
\left({ }^{\circ} \mathrm{C}\right)\end{array}$ & $\begin{array}{c}\text { Mass of coffee husk } \\
(\mathrm{kg})\end{array}$ & $\begin{array}{c}\text { Mass of char } \\
(\mathrm{kg})\end{array}$ & $\begin{array}{c}\text { Ash content } \\
(\%)\end{array}$ & $\begin{array}{c}\text { Volatile matter } \\
(\%)\end{array}$ & $\begin{array}{c}\text { Fixed carbon } \\
(\%)\end{array}$ & $\begin{array}{c}\text { Yield } \\
(\%)\end{array}$ & $\begin{array}{c}\text { Fixed carbon yield } \\
(\%)\end{array}$ \\
\hline 200 & 15 & 5.35 & 8.5 & 80 & 52 & 67 & 42 \\
300 & 15 & 4.75 & 9.6 & 39 & 73 & 45 & 68 \\
400 & 15 & 1.45 & 10.2 & 35 & 77 & 43 & 71 \\
500 & 15 & 1.3 & 10.5 & 26.4 & 85 & 42 & 95 \\
\hline
\end{tabular}

3.2.2. Effect of Heating Time. The effect of heating value on yield and quality of char are presented in Table 4 .

The effect of heating time is nearly identical to that of the temperature. As the heating time is increased, the yield of char falls but the quality of char improves, as indicated in Figure 11.

This could be because prolonging the heating period at high temperatures $\left(500^{\circ} \mathrm{C}\right)$ caused the volatile fractions to break, even more, resulting in low molecular weight liquids and gases instead of char. In addition, as the heating period at high temperature is increased, the dehydration of biomass hydroxyl groups and thermal degradation of cellulose and lignin may occur [44] (Figure 11).
3.2.3. Calorific Value of Fuel Briquette. The calorific value of fuel briquette was carried out in the laboratory at the Geological Survey of Ethiopia in Addis Ababa. The calorific value was determined by the Parr oxygen bomb calorimeter and adiabatic calorimeter analysis in accordance with the CEN/TS14918 standard method [38]. The results showed that fuel briquette made up of coffee husk has a calorific value which is around $8,480 \mathrm{cal} / \mathrm{g}$. The calorific value of the fuel briquettes obtained in this research was greater than the calorific value of fuel briquettes produced from grass which was $3817.6 \mathrm{cal} / \mathrm{g}[34,45]$. All produced briquettes in this research have higher calorific values than wood which has a calorific value of $3,296.82 \mathrm{cal} / \mathrm{g}[16,46,47]$. 


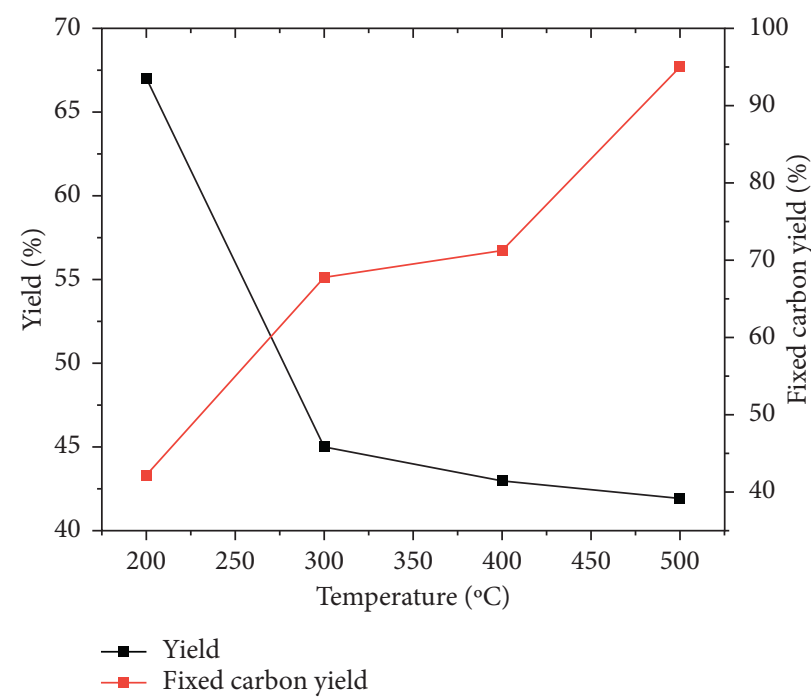

Figure 10: Effect of temperature on yield and quality of char.

TABlE 4: Effect of heating time on yield and quality of char.

\begin{tabular}{lccccccc}
\hline Time (hr) & Mass of coffee husk (kg) & Mass of char. (kg) Ash content (\%) & Volatile matter (\%) & $\begin{array}{c}\text { Fixed carbon } \\
(\%)\end{array}$ & $\begin{array}{c}\text { Yield } \\
(\%)\end{array}$ & $\begin{array}{c}\text { Fixed carbon yield } \\
(\%)\end{array}$ \\
\hline 1 & 1 & 0.38 & 5.71 & 38.26 & 56.03 & 38 & 48.4 \\
2 & 1 & 0.35 & 6.01 & 35.43 & 58.56 & 35 & 50 \\
3 & 1 & 0.30 & 10.53 & 23.90 & 65.57 & 30 & 58 \\
\hline
\end{tabular}

3.2.4. Effect of Binders on Calorific Value. A binder is simply something which that holds the fuel briquette together while it is being moved about or while it is burning. Adhesiveness is the most basic and important quality to look for in a binder. Clay will act as a binder, but the powdery residue blocks the passage of radiant heat, and much of the heating value of the charcoal is lost. Briquettes prepared with tar or molasses have to be heat-treated to drive off the volatiles that has been added. The results showed that the coffee husk with clay has a calorific value of $30.543 \mathrm{MJ} / \mathrm{Kg}$, coffee husk with starch has $22 \mathrm{MJ} / \mathrm{Kg}$, and coffee husk with molasses has $24.098 \mathrm{MJ} / \mathrm{Kg}$. From these results, it can be concluded that molasses is the best binder. But it has some drawbacks. For example, the briquette produced from molasses as a binder has an unpleasant smell during the initial phase of burning. To avoid this, the fuel briquette should be thermally treated before use, called curing. The clay binder does not need any thermal treatment. It contributes to the calorific values of the briquette as compared with other types of binders.

\subsection{Health, Environmental, and Economic Implications.} From a health and hygiene, environmental, and economic standpoint, the fuel briquettes made from coffee husk offer greater advantages.

3.3.1. Health and Hygiene Implications. Coffee husk waste briquette carbon has more cost, health, and climate advantages. In contrast, this fuel briquette is a nonsmoking fuel, as wood carbonisation disappears. The smoke from wood charcoal fires can trigger a range of respiratory diseases in an indoor cooking environment (Table 5).

It is also a way to reduce toxic solid waste. Certain solid farm waste is rather indigestible; it cannot be used for food. Because it is a voluminous, small density biomass, it is hard to remove and cannot be burnt from the ground (Table 6). As chopped farm waste causes plenty of smoke, it cannot be used directly as fuel. Compression also requires considerable energy expenditure. On the other side, organic matter is considered to be burnt. Coffee husk briquettes are more effectively combusted, and no smoke is produced. As a consequence, these briquettes are not causing any respiratory diseases or indoor air pollution (Table 6).

3.3.2. Environmental Impact of Briquette. Instead of being burnt on fields, the use of coffee husk waste for fuelling slows down deforestation by eliminating the need to cut down fuelwood trees (Table 5). Another advantage is that less smoke is produced during combustion, resulting in fewer emission into the atmosphere. Each kilogram of charcoal briquette replaces 1.87 kilograms of firewood, preventing 2.95 kilograms of $\mathrm{CO}_{2}$ from entering the atmosphere. As a result, this fuel briquette offers a variety of benefits, including preventing deforestation by substituting wood fuel, reducing $\mathrm{CO}_{2}$ and other pollutants in the environment, and creating a clean environment by turning solid wastes such as coffee husk and other wastes into useable products. Since Ethiopia is dealing with an energy crisis and pollution, special attention should be paid to these types of alternative energy sources (Table 5). 


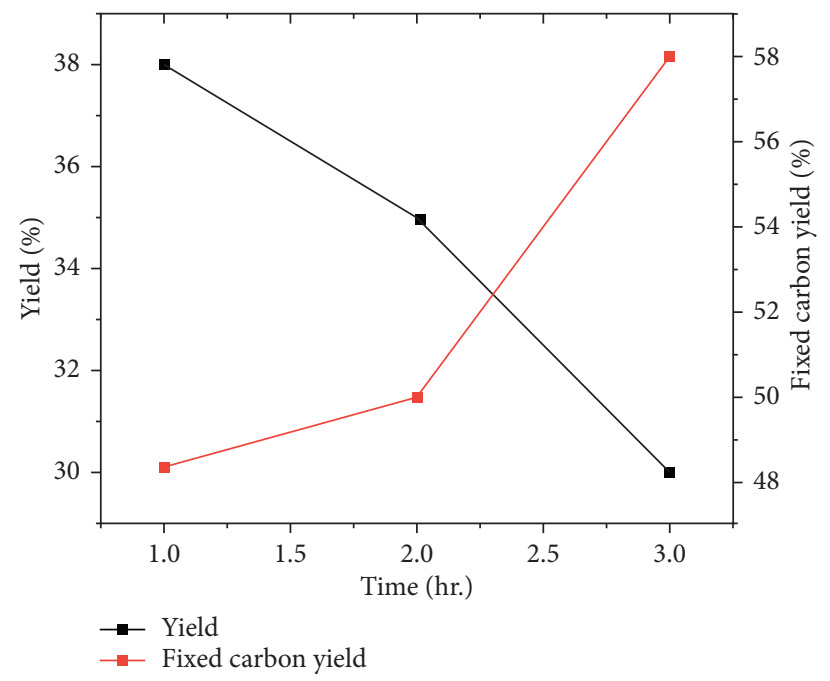

FIGURE 11: Effect of heating time on yield and quality of char.

TABLE 5: Fuel briquette and wood charcoal comparison analysis $[9,14]$.

\begin{tabular}{|c|c|c|}
\hline $\begin{array}{l}\text { S. } \\
\text { no. }\end{array}$ & Fuel briquette & Wood charcoal \\
\hline 1 & Smokeless & Smoke \\
\hline 2 & It exhibits faster heat release and greater heat value & It exhibits slower heat release and smaller heat value \\
\hline 3 & $\begin{array}{l}\text { When compared to the cost of purchasing wood charcoal, the production } \\
\text { cost is low }\end{array}$ & The local market has a high cost of production \\
\hline 4 & It reduces the impact of deforestation & It increases the effects of deforestation \\
\hline 5 & It has a long burn period $(2-3 \mathrm{hr})$ & $\begin{array}{l}\text { It has the ability to burn for a limited period of time } \\
\qquad(1-2 \mathrm{hr})\end{array}$ \\
\hline
\end{tabular}

TABLE 6: Comparison of the processes of producing wood charcoal and fuel briquette [10].

\begin{tabular}{lcc}
\hline $\begin{array}{l}\text { S. } \\
\text { no. }\end{array}$ & Fuel briquette & Wood charcoal \\
\hline 1 & No need for digging & Digging on the ground is \\
needed & It is not mobile \\
2 & Preparing shallow pit of charring mobile (Its versatility enables it to operate at harvesting sites, & Sometimes, it is fire \\
3 & farmsteads, and other locations.) & hazardous \\
4 & It is safe in the view of health factor & It is not safe
\end{tabular}

3.3.3. Economic Implications. As fuel briquettes are considered an advanced fuel, due to their clean-burning nature and their ability to be stored for long periods with no degradation, this allows the development of microbusiness. Briquette can be made out of agricultural waste and sold by any entrepreneur in a local market for personal benefit. In the economy, instead of diverting more money to international fuels, individual entrepreneurs and the country as a whole should boost their wealth by turning something previously unused into an income stream (Table 5).

\section{Conclusion and Recommendations}

4.1. Conclusions. This study found that briquettes made from coffee husk have many potentials as an environmentally friendly energy source. It reduces pollution while also providing a safe way to dispose of coffee waste. Furthermore, by offering renewable, clean, and sustainable energy as a replacement for fuelwood and charcoal, the manufacture of briquettes from coffee husk helps to increase the process of carbon sequestration by reducing deforestation. This study entails converting coffee husk to char in an environmentally friendly, continuous batch process, briquetting the char into a solid fuel shape and using a reliable, clean, and user-friendly stove explicitly designed for briquettes as fuel. The briquette manufacturing technologies used in each phase are simple to introduce in rural areas, opening new revenue streams in the Mettu region. The technology promises to turn coffee husk waste into a costeffective and environmentally sustainable briquette fuel for 
households, restaurants, and small businesses. National research institutions and Mettu University should make a concerted effort to promote, develop, and disseminate this briquetting technology for the benefit of the society.

4.2. Recommendations for Future Work. The fuel briquettes produced from coffee husk are economic, environmentally friendly, and healthy and reduce the impact of deforestation. The following tasks are to be recommended in the future:

(i) The next researcher can construct an automatic molder machine that produces multiple briquettes in the batch process.

(ii) The combustion (carbonisation) process of the coffee husk was taking too much time. So, one can minimize the carbonisation process of the coffee husk.

(iii) The next researcher can obtain the ignition properties and efficiency of the fuel briquette.

\section{Data Availability}

The data that support the findings of this study are available from the corresponding author upon reasonable request.

\section{Conflicts of Interest}

The authors declare that there are no conflicts of interest.

\section{Acknowledgments}

The authors are very grateful to Mettu University Research and Technology Transfer Directorate for the financial support. They are also thankful to Dagim and Dechaok coffeeprocessing industries and the Geological Survey of Ethiopia, Geochemical Testing Laboratory, for providing their laboratory facilities to perform the experimental analysis. Last but not least, they are also grateful to Mettu University, mechanical engineering department staff, and laboratory assistants for their support for the completion of the overall study.

\section{References}

[1] MoWE, Scaling - up Renewable Energy Program Ethiopia Investment Plan, Ministry of Water and Energy,Federal Democratic Republic of Ethiopia, Addis Ababa, Ethiopia, 2012, https://www.h4sd.info.

[2] Y. Mulugetta, "Renewable energy technology and implementation mechanisms for Ethiopia," Energy Sources, Part B: Economics, Planning and Policy, vol. 2, no. 1, pp. 3-17, 2007.

[3] A. Dingeto Hailu, D. K. Kumsa, and D. Kalbessa Kumsa, "Ethiopia renewable energy potentials and current state," AIMS Energy, vol. 9, no. 1, pp. 1-14, 2021.

[4] U. Renewable, E. Program, and D. Final, "Federal democratic republic of Ethiopia ministry of water and energy," 2012.

[5] D. Cervantes-Godoy, J. Dewbre, C. J. Amegnaglo et al., "The future of food and agriculture: trends and challenges," 2014, https://www.fao.org/publications\%0Ahttp://www.fao.org/3/ a-i6583e.pdf\%0Ahttp://siteresources.worldbank.org/ INTARD/825826-1111044795683/20424536/Ag_ed_Africa.
pdf\%0Awww.fao.org/cfs\%0Ahttp://www.jstor.org/stable/ 4356839\%0Ahttps://ediss.uni-goettingen.de/bitstream/han.

[6] S. Sisbudi Harsono, "Coffee husk biopellet characteristics as solid fuel for combustion stove," Environmental Sciences: Current Research, vol. 2, no. 1, pp. 1-6, 2019.

[7] D.-G. Woo, S. H. Kim, and T. H. Kim, "Solid fuel characteristics of pellets comprising spent coffee grounds and wood powder," Energies, vol. 14, no. 2, p. 371, 2021.

[8] E. Bondesson, A Nutritional Analysis on the by-Product Coffee Husk and its Potential Utilization in Food Production, Swedish University of Agricultural Sciences, Uppsala, Sweden, 2015.

[9] A. Haddis, E. Alemayehu, and A. Ambelu, "The potential of coffee husk and pulp as an alternative source of environmentally friendly energy east african journal of sciences," 2014.

[10] M. W. Mbugua, M. W. Kimani, B. N. K. Njoroge, A. N. Gitau, J. M. Mutua, and A. K. Luvai, "Characterization of the physical parameters of coffee husks towards energy production," IJETAE, vol. 4, 2014.

[11] M. W. Mbugua, M. W. Kimani, B. N. K. Njoroge, A. N. Gitau, J. M. Mutua, and A. K. Luvai, "Characterization of the physical parameters of coffee husks towards energy production," Int. J. Res. Eng. Sci.vol. 2, pp. 1-5, 2014, http://www. springerlink.com/index/10.1007/978-3-540-77568-3\% 0Ahttp://www.scielo.br/scielo.php?script=sci arttext\&pid=S1413-70542014000500005\&lng=en\&tlng=en.

[12] K. Meharu, "Briquette from coffee husk," Journal of Waste Management and Disposal, vol. 2, pp. 1-9, 2019.

[13] E. Yandri, B. Novianto, F. Fridolini et al., "The technical design concept of hi-tech cook stove for urban communities using non-wood agricultural waste as Fuel sources," E3S Web of Conferences, vol. 226, pp. 00015-00019, 2021.

[14] A. Belay, "Current status, future potential and barriers for renewable energy development in Ethiopia (short communication)," Iranian Journal of Energy and Environment, vol. 10, no. 4, pp. 269-274, 2019.

[15] T. H. Mwampamba, M. Owen, and M. Pigaht, "Opportunities, challenges and way forward for the charcoal briquette industry in Sub-Saharan Africa," Energy for Sustainable Development, vol. 17, no. 2, pp. 158-170, 2013.

[16] Fao, Bioenergy and Food Security (BEFS), Improved Charcoal Technologies and Briquette Production from Woody Residues in Malawi, http://www.fao.org/3/CA2087EN/ca2087en.pdf, 2018.

[17] A. Mekonnen, "Rural household fuel production and consumption in Ethiopia: a case study," University, 1997.

[18] J. H. Peng, H. T. Bi, S. Sokhansanj, and J. C. Lim, "A study of particle size effect on biomass torrefaction and densification," Energy and Fuels, vol. 26, no. 6, pp. 3826-3839, 2012.

[19] J. Mart and M. L. Rodr, "Determination of the optimal operative conditions for the torrefaction of olive waste biomass," Sustainability, vol. 12, no. 16, pp. 1-11, 2020.

[20] A. Trubetskaya, J. J. Leahy, E. Yazhenskikh et al., "Characterization of woodstove briquettes from torrefied biomass and coal," Energy, vol. 171, pp. 853-865, 2019.

[21] A. Trubetskaya, J. Grams, J. J. Leahy et al., "The effect of particle size, temperature and residence time on the yields and reactivity of olive stones from torrefaction," Renewable Energy, vol. 160, pp. 998-1011, 2020.

[22] M. Temmerman, "Briquette production manual," p. 36, 2019.

[23] “T. For, A. Energy, I. Generation, I. Rural, biomass charcoal," 2010.

[24] S. Feleke, F. Haile, D. Genene et al., "Production and characterization of charcoal briquette from oxytenanthera 
abyssinica , arundinaria alpina , Acacia melifera and prosopis juliflora," J. Sci. Innov. Res.vol. 9, pp. 16-21, 2020, https:// www.jsirjournal.com.

[25] Astm, "Standard test methods for direct moisture content measurement of wood and wood-base materials," Annual Book of ASTM Standards, vol. 92, pp. 1-6, 2007.

[26] Astm D4442, "Standard test methods for direct moisture content measurement of wood and wood-base materials," Annual Book of ASTM Standards, vol. 92, pp. 1-6, 2003.

[27] A E872-82, Standard Test Method for Volatile Matter in the Analysis of Particulate wood fuels, ASTM International, West Conshohocken, 2013.

[28] “E. Of, O. Of, 24 - d," 2020.

[29] V. M. Sinks, W. Rees, F. a Coolican, and E. D. Pierron, "Comparison of methods for determination of volatile matter and ash in coal," Illinois State Geological Survey Circular, vol. 240, pp. 1-8, 1957.

[30] "Ethiopia standard," Ethiopian standard, vol. 598, p. 2001, 2017.

[31] “T.S. Preview," INTERNATIONAL STANDARD iTeh STANDARD PREVIEW iTeh STANDARD PREVIEW, vol. 2020, 2020.

[32] M. Fekadu Kedir, T. Bekele, and S. Feleke, "Problems of Mirt, and potentials of improved Gonzie and traditional open cook stoves in biomass consumption and end use emission in rural wooden houses of Southern Ethiopia," Scientific African, vol. 3, Article ID e00064, 2019.

[33] S. Y. Kpalo, M. F. Zainuddin, and L. A. Manaf, "Production and characterization of hybrid briquettes from corncobs and oil palm trunk bark under a low pressure densification technique," Sustainability.

[34] I. Onukak, I. Mohammed-Dabo, A. Ameh, S. Okoduwa, and O. Fasanya, "Production and characterization of biomass briquettes from tannery solid waste," Recycling, vol. 2, no. 4, p. 17, 2017.

[35] W. Merete, A. Haddis, E. Alemayehu, and A. Ambelu, "The potential of coffee husk and pulp as an alternative source of environmentally friendly energy," East African Journal of Sciences, vol. 8, pp. 29-36, 2014.

[36] "TAPPI T211, T211 Ash in wood, pulp, paper and paperboard: combustion at $525{ }^{\circ} \mathrm{C}$, TAPPI Stand," vol. 5, 2007 Test Methods. T211 om-02.

[37] F. Feng, W. Y. Liu, Y. S. Chen, Q. L. Guo, and Q. D. You, "Study on derivatives of gambogic acid," Journal of China Pharmaceutical University, vol. 36, pp. 302-305, 2005.

[38] Astm-American Society For Testing Material, "Standard test method for ash on wood," Man. Hydrocarb. Anal.vol. 84p. 2, 6th edition, 2007.

[39] p. 97, 2003 B. Statements, ht tp an ua nd ar ds bl og sp o t. c m an nd ar bl og sp o t. c.

[40] AASHTO T 19/T 19-14, Bulk Density (Unit Weight) and Voids in Aggregate AASHTO Designation: T 19/T 19-14 ASTM Designation: C29/C 29M-07, (n.d.).

[41] vol. 97, no. 2003, pp. 3-4, 2003, B. Density, C 29/c 29m - 97.

[42] T. L. Resins, "Standard test method for measuring bulk density values of powders and other bulk," Significance, vol. i, pp. 6-9, 1995.

[43] European Committee Standardization (Cen), “TS 14918: 2005 - solid biofuels - methods for the determination of calorific value," p. 66, 2005.

[44] E. A. Varol, "Rapid and slow pyrolysis of pistachio shell: effect of pyrolysis conditions on the product yields and characterization of the liquid product," pp. 506-514, 2007.
[45] E. G. Messay, A. A. Birhanu, J. M. Mulissa, T. A. Genet, W. A. Endale, and B. F. Gutema, "Briquette production from sugar cane bagasse and its potential as clean source of energy," African Journal of Environmental Science and Technology, vol. 15, no. 8, pp. 339-348, 2021.

[46] 1999 T. Session, Thirtieth Session.

[47] Fao, Food Insecurity in the World 1999, State Food Insecurity World 1999, pp. 1-35, 1999, http://www.fao.org/News/1999/ img/SOFI99-E.PDF. 